\title{
3D P-wave velocity image beneath the Pannonian Basin using traveltime tomography
}

\author{
Máté Timkó ${ }^{1}$ D $\cdot$ István Kovács ${ }^{1,2} \cdot$ Zoltán Wéber $^{1}$
}

Received: 30 July 2019 / Accepted: 7 August 2019 / Published online: 23 August 2019

(c) The Author(s) 2019

\begin{abstract}
The Pannonian region is a back-arc basin located within the arcuate Alpine-Carpathian mountain chain in central Europe. Beneath the basin both the crust and the lithosphere have smaller thickness than the continental average. During the last few decades several studies have been born to explain the formation of the Pannonian Basin but several key questions remain unanswered. In this study we construct a new high-resolution 3D P-wave velocity model of the crust and uppermost mantle in the Pannonian Basin which may help us to understand better the structure and evolution of the region. For the 3D P-wave velocity structure estimation over 32 thousand traveltime picks have been derived from the ISC bulletin and the local Hungarian National Seismological Bulletin, and altogether we used more than 3200 seismic events (local, near-regional and regional) and more than 150 seismic stations from the time period between 2004 and 2014. For the 3D velocity field inversion we used the FMTOMO software package which uses the so called Fast Marching Method for calculating the traveltime estimations, and the subspace inversion method to recover the model parameters. We also performed several checkerboard tests both to select the appropriate regularization parameters and to help the interpretation of the resulting $\mathrm{P}$-wave velocity model. On the resulting tomographic image the seismic velocity anomalies well resolve the effects of deep sedimentary basins and also Moho topography and the associated updomings of the asthenosphere below the Pannonian Basin. Different major tetonic units and fault zones separating those seem to show characteristic velocity anomalies. Subrecent volcanic activity or associated melt and fluid percolation, heat transfer in the upper mantle and crust may also have an impact on the propagation of seismic waves.
\end{abstract}

Keywords Pannonian Basin · Traveltime tomography · P-wave velocity · Inverse theory · Fast Marching Method

Máté Timkó

timko.mate@csfk.mta.hu

1 Geodetic and Geophysical Institute, Research Centre for Astronomy and Earth Sciences, Hungarian Academy of Sciences, Csatkai E. u. 6-8., Sopron 9400, Hungary

2 MTA CSFK Lendület Pannon LitH2Oscope Research Group, Sopron, Hungary 


\section{Introduction}

The Pannonian Basin (Figs. 1, 2) is a back arc basin located within the arcuate Alpine-Carpathian mountain chain. Together with the Aegean Trough and the Western Mediterranean basins it forms one of the backarc basins in the tectonically active broader Mediterranean region. Its evolution is ultimately linked with slab rollback, asthenospheric updoming, and formation of the Carpathian mountain chain in the east and the Alpine-Dinaric orogeny in the west. Tectonically the Pannonian Basin comprises the AlCaPa unit that is of Adriatic origin and the Tisza-Dacia unit that is of Eurasian affinity. These units are separated by the Mid-Hungarian zone that is not associated with pronounced lateral variations in the topography. However the boundaries of the main tectonic units are less well defined.

The formation of the Pannonian Basin took place in the last 20 Ma (e.g. Faccenna et al. 2014; Handy et al. 2015; Horváth et al. 2015). Several models have been proposed to explain the extension in the Pannonian Basin within the collisional setting of the Alpine-Carpathian mountain chain but many key questions are still under debate. Often the thin lithosphere is interpreted as a result of thinning of a previously thicker lithosphere by subduction roll-back (Horváth 1993; Lenkey et al. 2002; Horváth et al. 2006), by delamination of mantle lithosphere (Houseman and Gemmer 2007; Ren et al. 2012), asthenospheric flow (Kovács et al. 2012; Király et al. 2018; Song et al. 2019). The presence of widespread Miocene calc-alkaline volcanism (Kovacs and Szabó 2008; Harangi

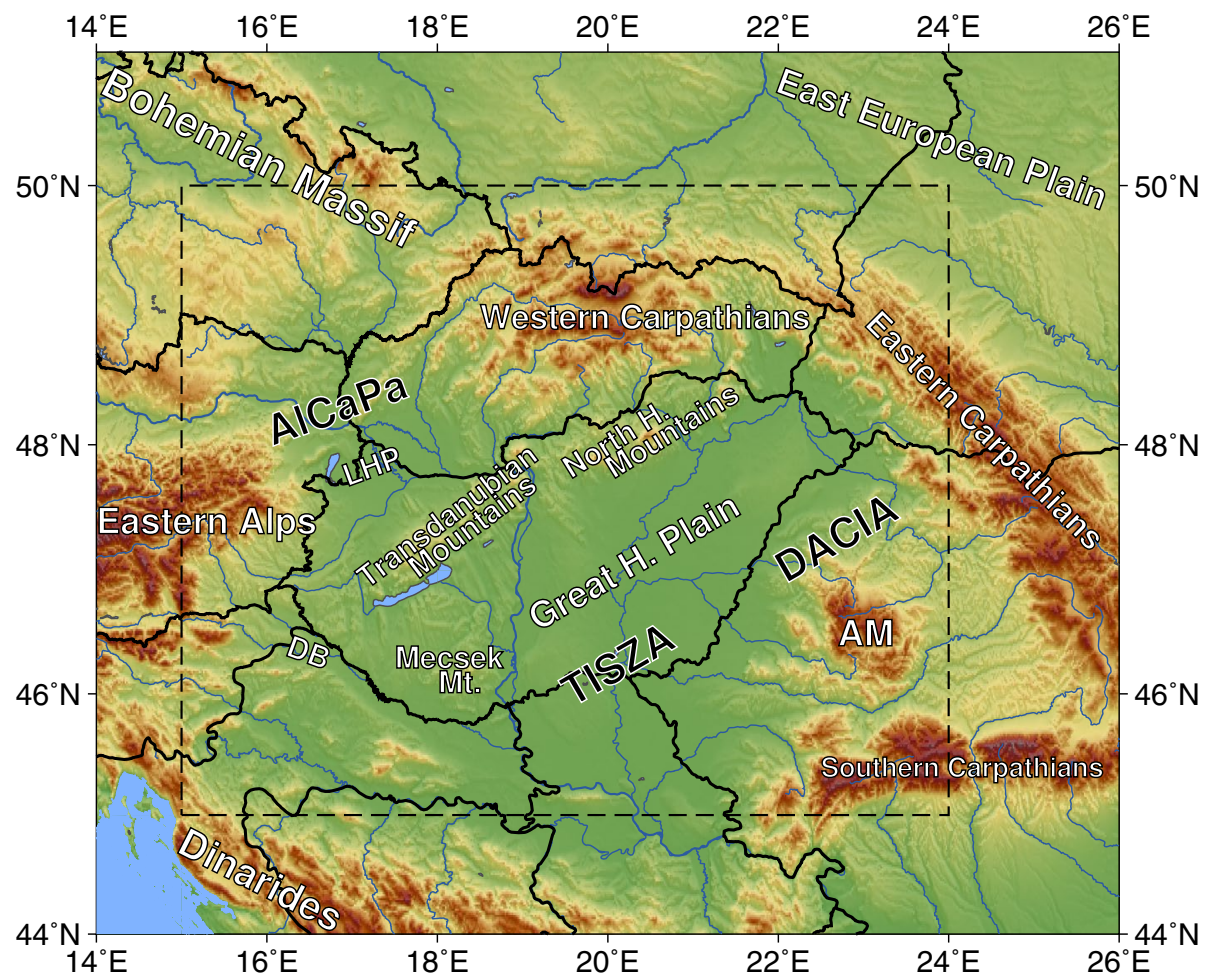

Fig. 1 The Pannonian Basin and the surrounding regions. Tectonic domains: DB Dráva Basin, LHP Little Hungarian Plain, $A M$ Apuseni Mountains. The dashed line indicates the research area 


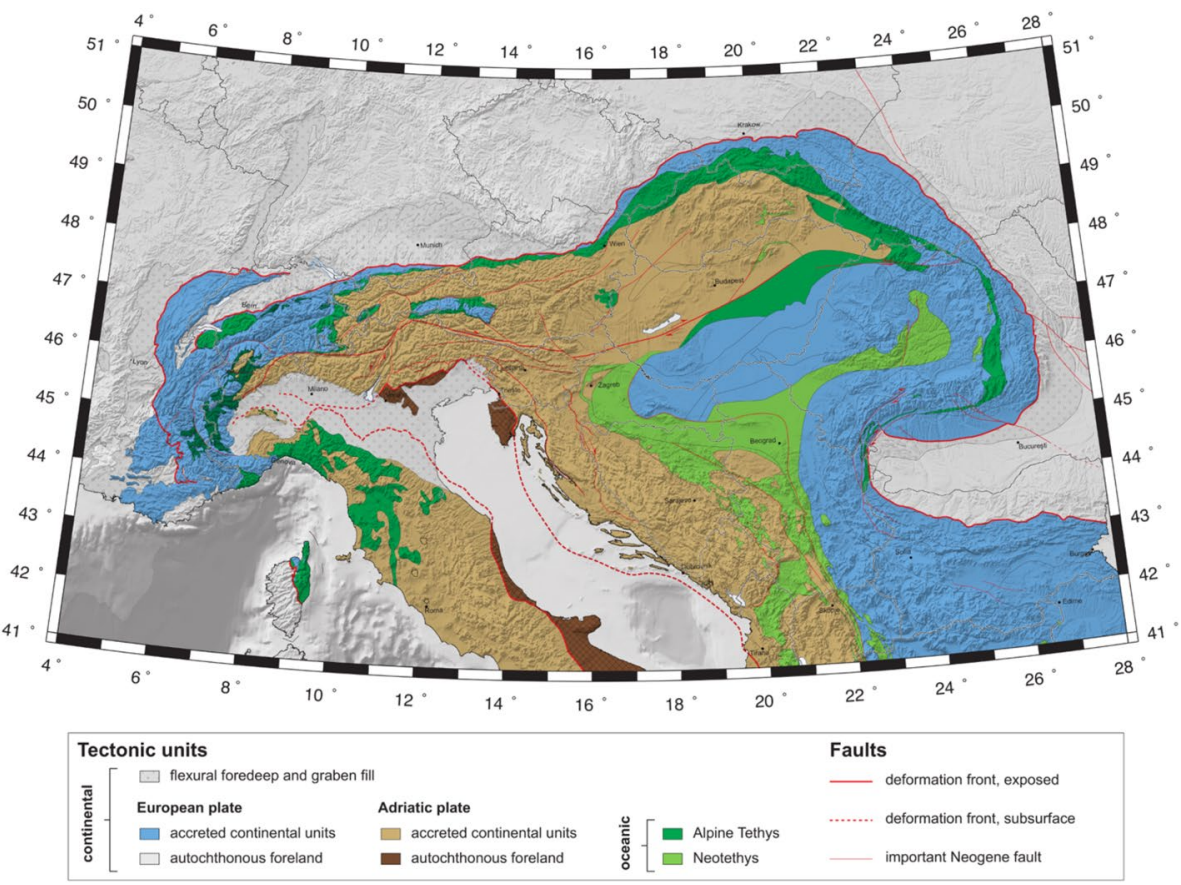

Fig. 2 Tectonic map of the greater Alpine orogen region with the main structural features (Hetényi et al. 2018)

and Lenkey 2007; Seghedi et al. 2004) was also associated with this extension. In the last few decades it became clear that the recent compressional tectonic setting (i.e. tectonic inversion) is a result of the counter-clockwise rotation and realative northeast movment of the Adriatic microplate (e.g. Bada et al. 2007; Bus et al. 2009).

The crust in the Pannonian Basin is quite thin. Its thickness ranges from 24 to $30 \mathrm{~km}$ beneath the basin and from 30 to $50 \mathrm{~km}$ beneath the surrounding orogenic regions (Grad et al. 2009; Kalmár et al. 2018). The lithosphere is also thinned but the topography of the lithosphere-asthenosphere boundary is not very well constrained. The average thickness of the lithosphere has been estimated to approximately $60-70 \mathrm{~km}$ in the center of the basin (Tari et al. 1999; Lenkey 1999). There are also indications for thin lithosphere and shallow asthenosphere from active seismic (Behm et al. 2007; Grad et al. 2006), receiver function (Kalmár et al. 2018; Hetényi et al. 2015) magnetotelluric (Praus et al. 1990; Ádám et al. 2017; Ádám and Wesztergom 2001) and tomographic (Szanyi et al. 2013; Dando et al. 2011; Ren et al. 2013) studies.

To decipher the evolution of the Pannonian Basin, it is pivotal to know the velocity structure of the area. Accordingly, in the last decades many seismological investigations were carried out. A huge portion of these studies were $2 \mathrm{D}$ refraction and reflection measurements mostly on the western and northern part of the Pannonian Basin (Behm et al. 2007; Grad et al. 2006). 3D seismic velocity models have also been developed recently, based on ambient noise and earthquake generated surface wave measurements (Szanyi et al. 2013; Ren et al. 2013; El-Sharkawy et al. 2017; Kästle et al. 2018). However, the last traveltime tomography calculations date back to the early 2000's (Bus 2001; Wéber 2002). 
Unfortunately, the resolution of these models is rather poor due to the sparse station density. During the last 20 years many new stations have been installed in the area leading to a huge improvement both in the number of arrival-time measurements and in the reliability of the hypocentre determinations (Gráczer et al. 2018). Using the collected large amount of good-quality data, in this study we construct a new high-resolution 3D P-wave velocity model of the crust and uppermost mantle in the Pannonian Basin.

After a short description of data collection and the applied method, we review the mathematical representation and the robostusness of the tomographic model. Then the achieved 3D P-wave velocity field based on the available permanent stations is discussed, followed by a detailed interpretation of the vertical and horizontal pattern of the obtained seismic velocity anomalies.

\section{Data and method}

To estimate the 3D velocity structure beneath the Pannonian Basin, we analyzed seismic traveltime data from the Bulletin of the International Seismological Centre (ISCB) (ISC 2013) and the local Hungarian National Seismological Bulletin (HNSB) (Bondár et al. 2018) for the seismic events that were recorded between the time period 2004 and 2014. In this study we combined local events occured in the research area and teleseismic earthquakes to accomplish a joint inversion. A majority of the collected phases were $P_{g}$ and $P_{n}$, but the dataset also included numerous $P$ phases owing to teleseismic earthquakes. Most of the local events occurred in the orogens near to the edges of the area, but only relatively a few events occur in the centre of the basin due to low seismicity. This combined dataset contained more than 65 million traveltime picks of more than 3.5 million hypocentre determinations. To standardize the data collection, we recalculated the traveltime residual, and primary- and secondary azimuthal gap (Bondár et al. 2004) values for all the events. The 1D traveltime predictions were calculated by the TauP software package (Crotwell et al. 1999). The applied 1D reference model has velocities in the upper mantle defined by the ak135 earth model (Kennett et al. 1995), and velocities varying in the crust-above $30 \mathrm{~km}$ - based on the Gráczer-Wéber model (Gráczer and Wéber 2012). For choosing the best input dataset (traveltime picks; hypocentre determinations) we used various filtering criteria (Table 1). These filtering parameters were optimized by maximizing the ratio between the number of events and the number of traveltime measurements.

This filtering process reduced the input tomographic dataset to $32,569 P_{n}, P_{g}$ and $P$ arrival pick data for 3267 seismic events at 150 seismic stations (Figs. 3, 4).

For the inversion we used the FMTOMO non-linear tomographic inversion software package (Rawlinson et al. 2006). The inversion procedure applies the multi-stage Fast Marching Method (FMM) (Rawlinson and Sambridge 2004) for calculating the forward step, and the subspace inversion method to retrieve the model parameters. The multi-stage FMM is a grid based eikonal solver algorithm which uses the finite-differences method that

Table 1 Optimal filtering criteria for local and teleseismic events

\begin{tabular}{lcll}
\hline & $\begin{array}{l}\text { Traveltime } \\
\text { residual }(\mathrm{s})\end{array}$ & $\begin{array}{l}\text { Primary } \\
\text { azitumtal } \\
\text { gap }\left(^{\circ}\right)\end{array}$ & $\begin{array}{l}\text { Secondary } \\
\text { azimuthal } \\
\text { gap }\left(^{\circ}\right.\end{array}$ \\
\hline Local earthquakes & $0 \pm 2.6$ & $<180$ & $<200$ \\
Teleseismic earthquakes & $0.6 \pm 1.5$ & $<120$ & $<160$ \\
\hline
\end{tabular}




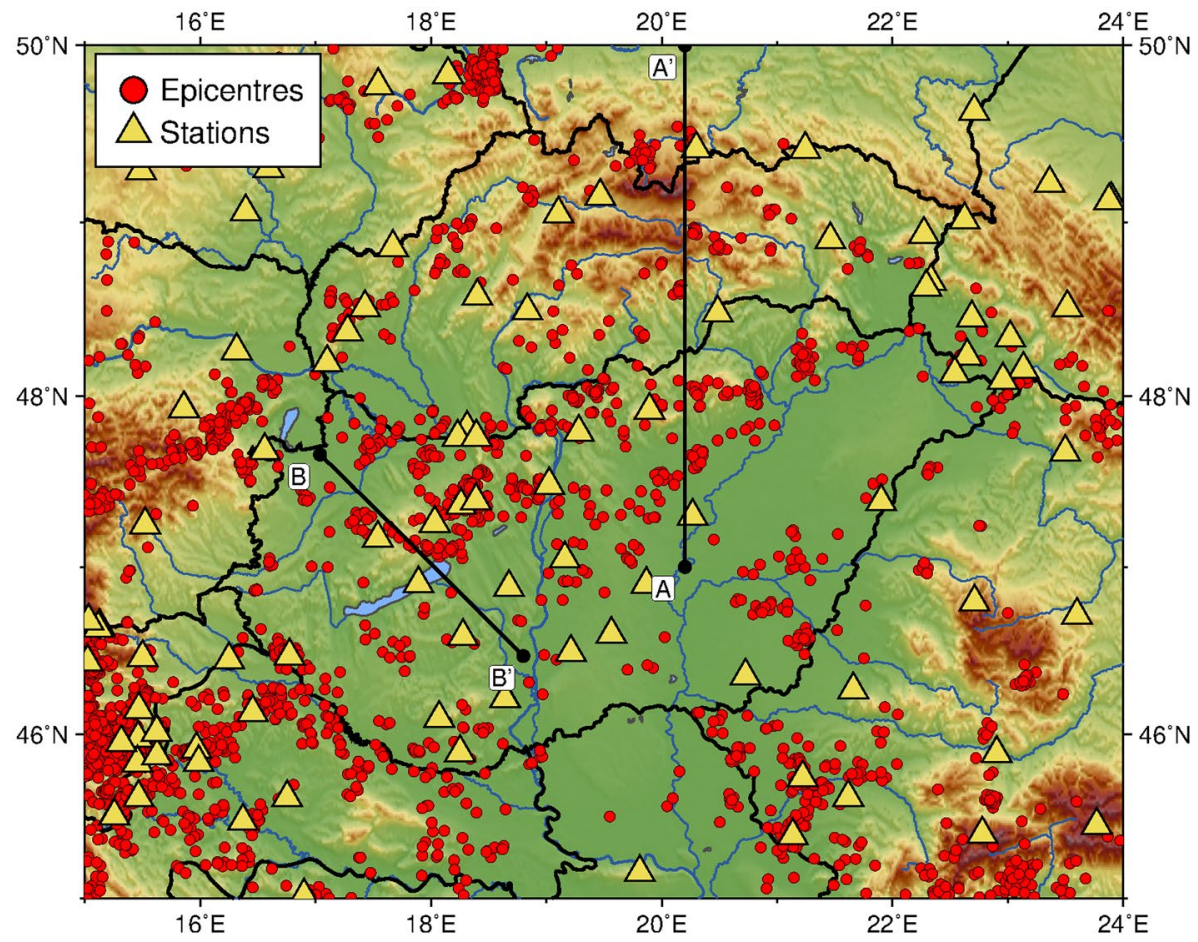

Fig. 3 Map showing the locations of the seismic stations (yellow triangles) and local earthquakes (red circles) used in this study. The black lines show the vertical sections in Figs. 10 and 11. (Color figure online)

implicitly tracks the evolution of wavefronts in 3D layered media. This approach allows us to calculate multiple types of body wave datasets including local reflections $\left(P_{g}\right)$, refractions $\left(P_{n}\right)$, and teleseismic $(P)$ data. Moreover, the software can invert simultaneously for variations in velocity field, interface depth and source location. The software can also use a semi-adapvive grid that is useful when it is needed to reduce the number of unknows in the deeper zones due to the lack of seismic rays.

The cost function minimized by FMTOMO to solve the inverse problem has the following shape:

$$
S(\mathbf{m})=\frac{1}{2}[\Psi(\mathbf{m})+\epsilon \Phi(\mathbf{m})+\eta \Omega(\mathbf{m})]
$$

where $\epsilon$ and $\eta$ are the damping and smoothing factors, respectively. The $\Psi(\mathbf{m})$ part of $S(\mathbf{m})$ expresses the distance between the predicted and measured traveltime measurements. This term is followed by two regularization terms where $\Phi(\mathbf{m})$ controls the variance-distance from the reference model - and $\Omega(\mathbf{m})$ controls the smoothness of the model. Consequently, the damping and smoothing parameters have triple role in the cost function: they manage how well the model explains the measurements, how closely the final solution model is to the reference model and how smooth the solution model is. 


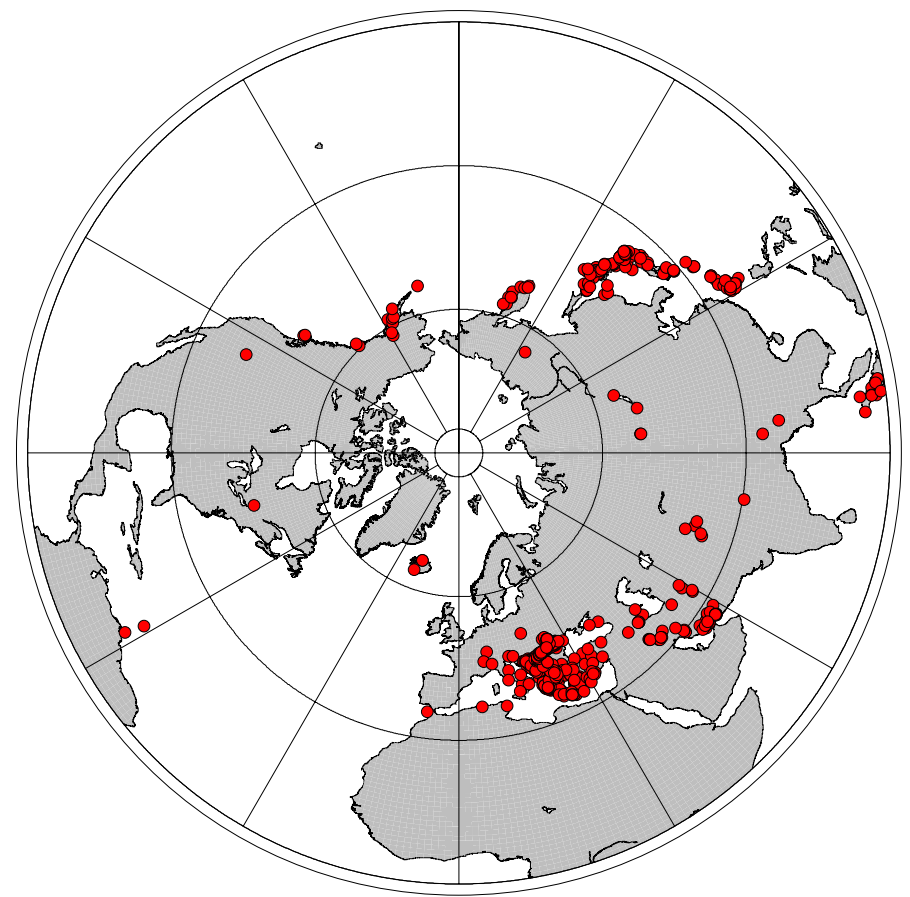

Fig. 4 Map showing the locations of the teleseismic and regional seismic events (red circles) from outside the research area. (Color figure online)

\section{Tomographic model}

In order to obtain the velocity structure in the crust and the uppermost mantle beneath the Pannonian basin, we used a rectangular tomographic model with a semi-adaptive grid. We defined a horizontal interface at $26 \mathrm{~km}$ depth to separate the crust and the upper mantle in terms of node spacing. A finer grid was used in the crust because the dataset is dominated by local seismic phases making better ray coverage in the upper part of the model. The grid spacing was approximately $20 \mathrm{~km}$ horizontally and $5.2 \mathrm{~km}$ vertically in the crust and $35 \mathrm{~km}$ horizontally and $9 \mathrm{~km}$ vertically in the upper mantle. Altogether, the model consists of $\sim 4500$ unknowns and spans $50 \mathrm{~km}$ in depth, $9^{\circ}$ in latitude and $5^{\circ}$ in longitude. The 1D reference or starting model for the inversion is based on velocity values obtained from the Gráczer-Wéber model (Gráczer and Wéber 2012). However, this model is only limited to the crust, so the ak135 global reference model is used to define velocities below $26 \mathrm{~km}$ in our model.

Before interpreting the seismic velocity images obtained by tomographic inversion, the robustness of the achieved model has to be investigated. Our inverse problem is overdetermined in general. The model, however, has some underdetermined regions mostly near to the sides and the deeper parts of the model due to the non-homogeneous source and reciever distribution and the lack of seismic phases below the Moho. In this mixed type of problems the solution is non-unique, so a lot of different models will satisfy the traveltime picks equally good. The best solution model can be found by specifying the appropriate regularization factors in the objective function. To analyze the robostusness of our model 
we performed checkerboard tests. For this process we build a synthetic model and solve the forward problem using the same source and receiver geometry as the real one. These synthetic data are then used to reconstruct the synthetic velocity patterns to indicate which regions of the model are well resolved during the inversion.

In our synthetic checkerboard test the size and the amplitude of the checkerboard anomalies were different in the crust and the upper mantle. We defined two layers of low- and high-velocity anomalies in the model space. The amplitude of the anomalies was $\pm 300 \mathrm{~m} / \mathrm{s}$ above and $\pm 500 \mathrm{~m} / \mathrm{s}$ below the Moho. Similarly, the size of the anomalies in the upper mantle were larger $\left(1.4^{\circ}\right.$ longitude $\times 0.9^{\circ}$ latitude $\times 26 \mathrm{~km}$ thickness $)$ than in the crust $\left(1^{\circ}\right.$ longitude $\times 0.6^{\circ}$ latitude $\times 26 \mathrm{~km}$ thickness). Gaussian noise with a standard deviation of $100 \mathrm{~ms}$ has been added to the synthetic dataset to simulate traveltime picking error. In order to choose the appropriate damping and smoothing factors, we performed 80 checkerboard tests. We tested every combination of the parameter values in Table 2, then we calculated model variance and model roughness for every resulting velocity image (Fig. 5). The appropriate damping and smoothing values would then be given by the values which resulted in the most accurate reconstruncion of the synthetic checkerboard model. Based on the trade-off surface in Fig. 5, the optimal damping and smoothing factors are $\epsilon=25$ and $\eta=25$ respectively. The optimum region has low roughness and model perturbation but adequately satisfies the data.

Figure 6 illustrates the recovered checkerboard synthetic test at depths of 10 and $30 \mathrm{~km}$. The checkerboard patterns are recovered in general very well in the crust beneath the Pannonian Basin, the Eastern-Alps and the southern part of the Western Carpathians. The quality of the restored anomalies in the upper mantle is acceptable but it gets poorer in the deeper parts of the model. In Fig. 6 the white line indicates that we judged to be the wellresolved area. This resolution test shows that the dataset used in this study is almost equally good for the interpretation of both the horizontal and vertical P-wave velocity anomalies (Fig. 7).

\section{Results}

In the final solution model the RMS data misfit reduced from 1201 to 902 ms after 6 iterations. The P-wave velocity maps in Figs. 8, 9, 10 and 11 show the tomographic images for the crust and the upper mantle. The white thick line in these figures indicates the wellresolved area according to the checkerboard tests. Interpreting the velocity anomalies outside of this area could be dubious due to poor ray coverage.

In the mid-crust at $10 \mathrm{~km}$ depth (Fig. 8) the Eastern Alps, the western part of the Western Carpahtians and the northern part of the Dinarides show high-velocity anomalies due to the crystalline rocks at shallow depths. The Northern Hungarian and Transdanubian mountain ranges have also positive anomalies. The Little Hungarian Plain, the Great Hungarian Plain and the Vienna Basin, however, exhibit lower velocities because

Table 2 The discrete values for the damping and smoothing factors that we used for the synthetic reconstruction tests

\begin{tabular}{ll}
\hline Damping factor & Smoothing factor \\
\hline$\{1,5,10,25,50,100,200,500\}$ & $\{1,5,10,25,50,100,150,250,500,1000\}$ \\
\hline
\end{tabular}




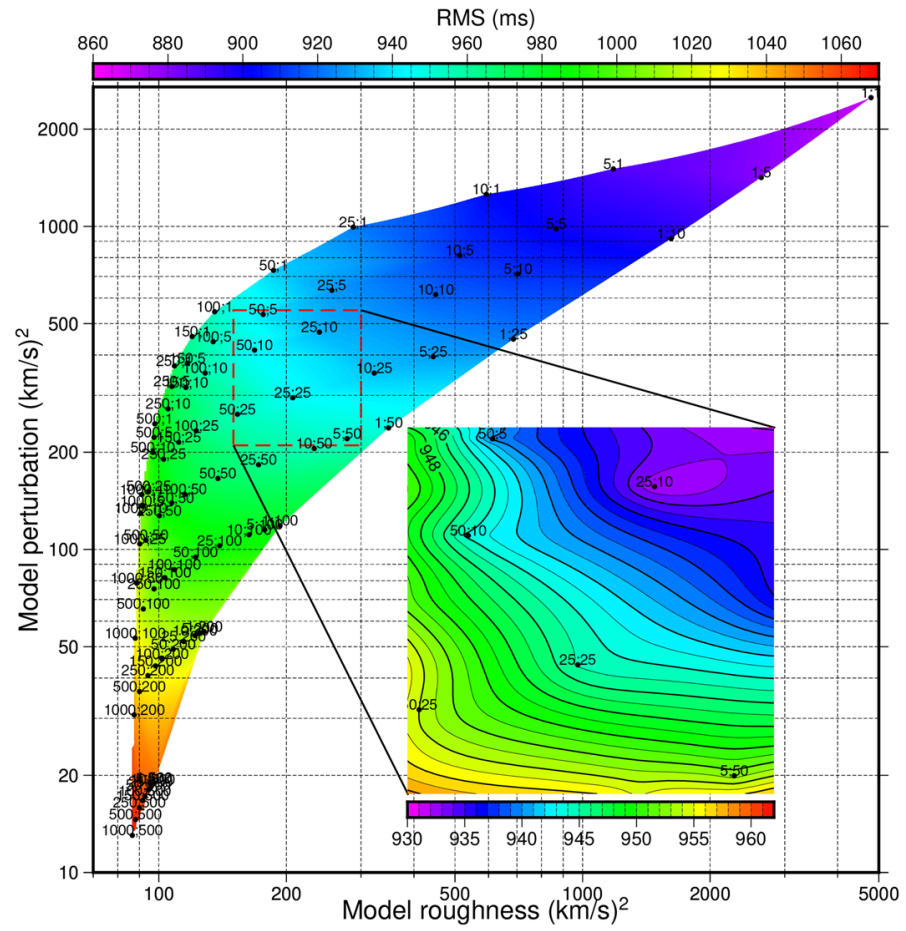

Fig. 5 Trade-off surface calculated using synthetic tests. The vertical and the horizontal axes show the model variance and the model roughness, respectively. Each black point indicates a synthetic test and the numbers above the points show the damping and smoothing factors. The red dashed line indicates the optimal zone. In this case the optimal damping and smoothing values are $\epsilon=25$ and $\eta=25$. (Color figure online)

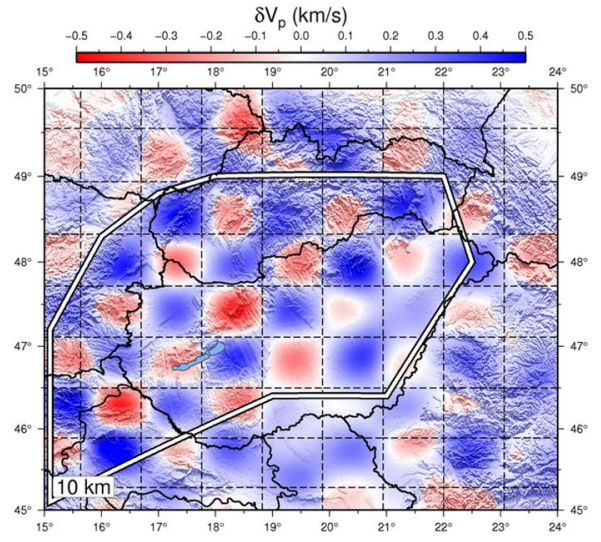

(a)

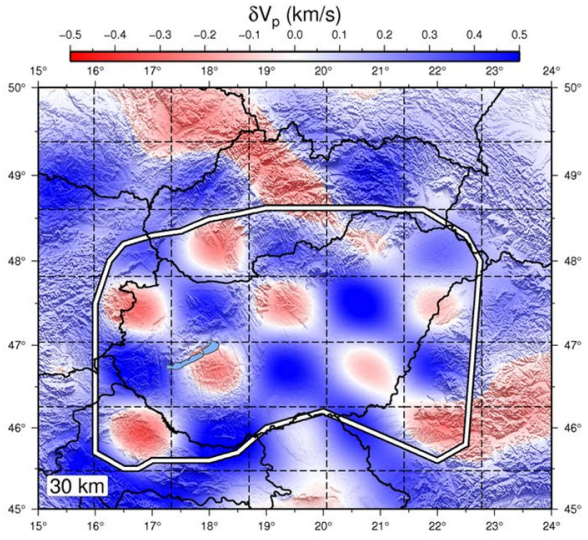

(b)

Fig. 6 The recovered checkerboard velocity model in the crust (left) and the uppermost mantle (right). The well-resolved area is marked with white line 


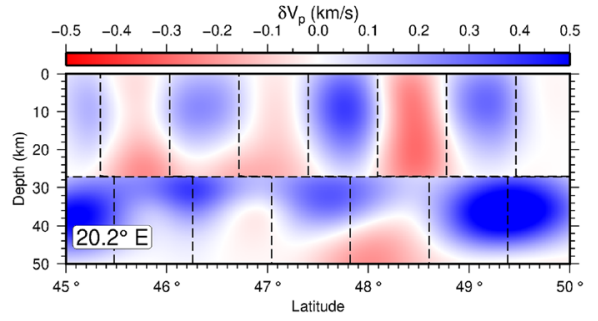

(a)

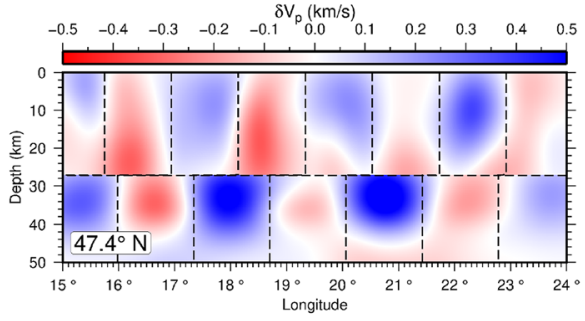

(b)

Fig. 7 Vertical section of the recovered checkerboard velocity model along the 20.2 longitude (left) and 47.4 latitude (right)

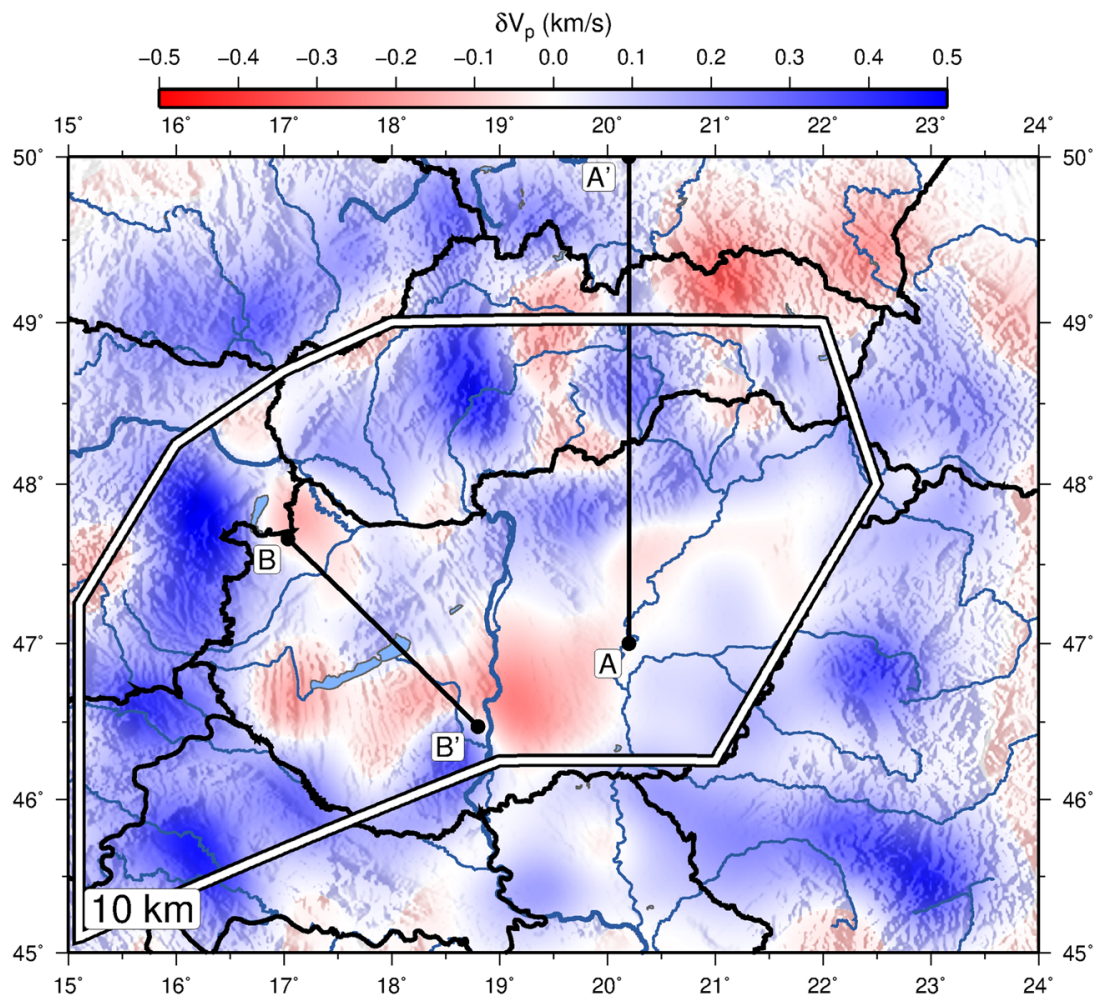

Fig. 8 P-wave velocity distribution at $10 \mathrm{~km}$ depth. The white continous line encircles the well-resolved area. The black lines show the vertical sections in Figs. 10 and 11

of the thick sedimentary layers in the basins. The sediment thickness in some of these subbasins may exceed $7-8 \mathrm{~km}$ so the resulting low-velocity anomalies are not surprising (i.e. Balázs et al. 2016). The obtained low-velocity bodies in the Western Carpathians may be related to the vulcanic activity in the area since the Miocene (Konečný et al. 1995; Harangi 2001; Seghedi et al. 2004). 


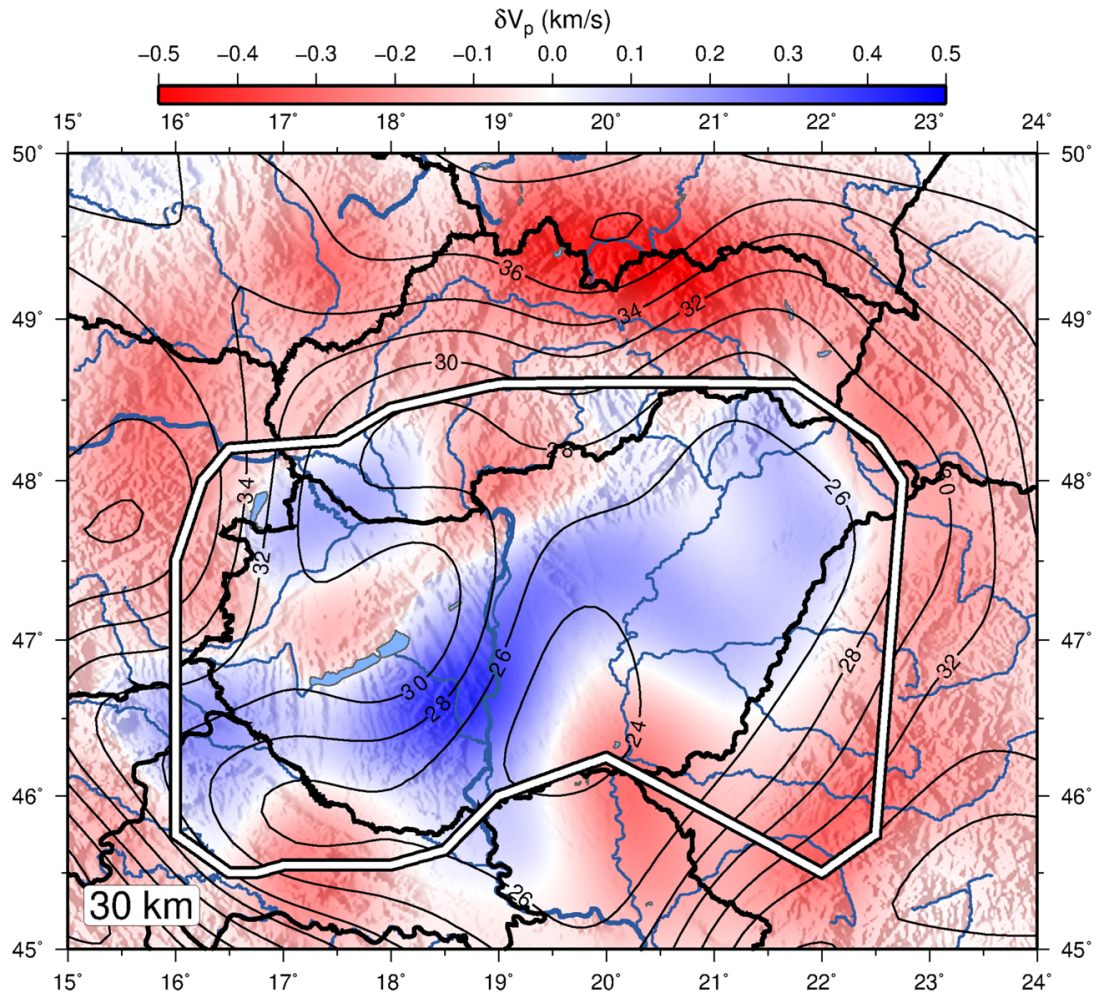

Fig. 9 P-wave velocity distribution at $30 \mathrm{~km}$ depth. The white continous line encircles the well-resolved area whereas the thin black contour lines show the Moho depth after (Grad et al. 2009)

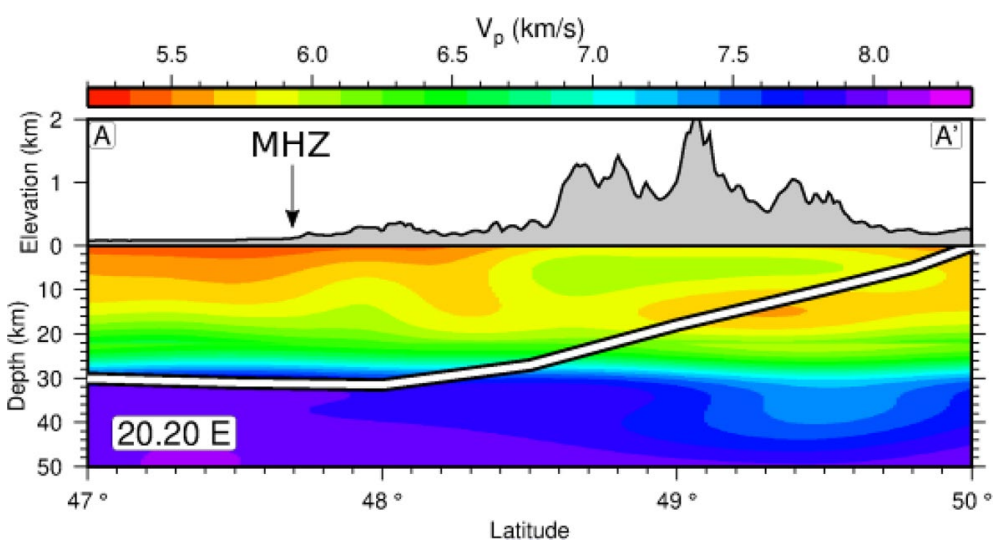

Fig. 10 Vertical P-wave velocity section along longitude 20.2. The arrow indicates the Mid-Hungarian Zone 


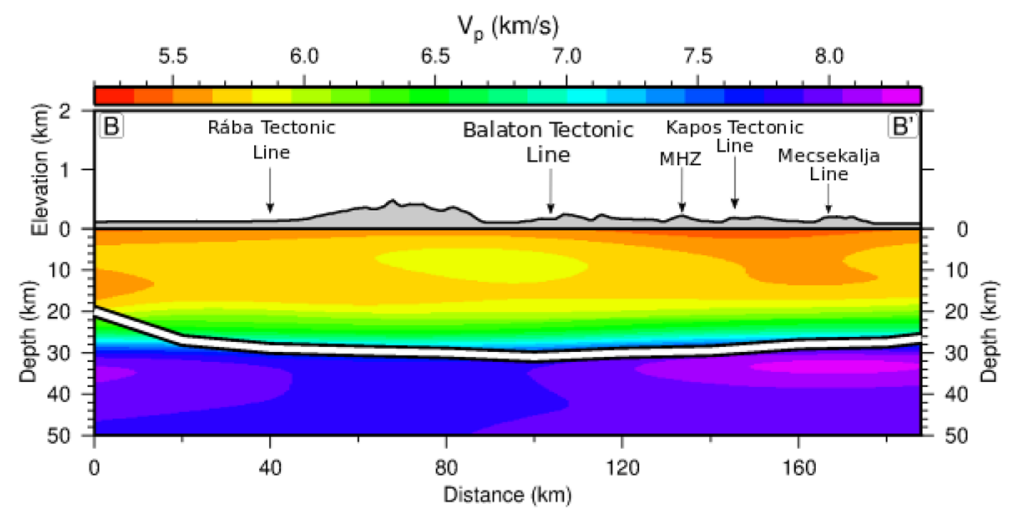

Fig. 11 Vertical P-wave velocity section along the CEL-08 seismic profile. The arrows indicate the major tectonic lines

In the uppermost mantle or lowermost crust at $30 \mathrm{~km}$ depth (Fig. 9) the Pannonian Basin shows generally faster seismic velocities than the neighboring areas. The patterns of the velocity anomalies correlate well with the Moho topography. The depth of the Moho discontinuity is rather shallow beneath the Great Hungarian Plain, Little Hungarian Plain and the Drava Basin $(\sim 24-26 \mathrm{~km})$. The updoming upper mantle beneath these regions explains the resulting positive velocity anomalies. Beneath the orogens (e.g. Alps and Carpathians) and outside of the Pannonian basin, where the Moho is deeper than $30 \mathrm{~km}$, the tomographic inversion resulted in lower, typical crustal velocities. The negative anomalies are thus intelligible in these areas.

The only exception to these main observations is the Békés basin at the southern part of the Great Hungarian Plain. According to our current knowledge the crustal and lithospheric thickness beneath the Békés basin is the thinnest in the Pannonian basin (Posgay et al. 1995), so here we would expect high-velocity anomalies. So the existence of the resulting negative anomaly may need more investigation, at the present time we may just hypothesize that melts/fluids residing in the overthinned lithosphere from the updomed asthenosphere may contribute to this negative velocity anomaly.

The vertical sections in Figs. 10 and 11 show two slices: one along longitude $20.2^{\circ}$, from the Great Hungarian Plain to the Western Carpathians and another along the CEL-08 seismic profile (Kiss 2009).

In the Fig. 10 a strong velocity difference appears in the near surface layers between the Western Carpathians and the Great Hungarian Plain. This contrast in the velocity field could be linked to the effect of the thick sediment layers beneath the Great Hungarian Plain. Another feature is that higher seismic velocities occur in shallower depth in the vicinity of the Mid-Hungrarian Zone.

In Fig 11 the crust under the Transdanubian Central Range in the depth range between 5 and $15 \mathrm{~km}$ shows a positive velocity anomaly which is not present north of the Rába line and south of the Balaton line. A low velocity anomaly occurs beneath the Kapos and Mecsekalja lines extending down to lower crustal depth. The pattern is roughly similar to that determined by Kiss (2009), however the velocity anomalies seem to be contrasting. 


\section{Discussion and conclusions}

In this study we have performed an iterative non-linear tomography scheme to jointy invert local and teleseismic eartquake datasets from the ISC bulletin and the HNSB for the 3D seismic crustal and uppermost mantle structure of the Pannonian Basin. We have used various filtering criteria to choose the most reliable hypocenter determinations and traveltime picks which were used during the inversion process. To determine the appropriate grid spacing and inversion parameters we have done several synthetic checkerboard tests. The careful analysis of the performed checkerboard tests also showed which regions are solved with high reliability during the inversion process.

The resulting 3D velocity image highly resembles the known geologic and tectonic structure of the area and is comperable to earlier tomographic images published in the literature. The detailed interpretation of the velocity anomalies leaded us to the following conclusions:

Seismic velocity anomalies well resolve the effects of deep sedimentary basins and also Moho topography and the associated updomings of the asthenosphere below the Pannonian Basin. Different major tetonic units and fault zones separating those seem to show characteristic velocity anomalies. Some of the anomalies extend down to the lower crust. Subrecent volcanic activity or associated melt and fluid percolation, heat transfer in the upper mantle and crust (e.g. Central Slovakian Volcanic field, Makó Basin) may also have an impact on the propagation of seismic waves.

Acknowledgements Open access funding provided by MTA Research Centre for Astronomy and Earth Sciences (MTA CSFK). The reported investigation was financially supported by the National Research, Development and Innovation Fund (Grant Nos. K124241 and 2018-1.2.1-NKP-2018-00007) and MTA CSFK Lendület Pannon LitH2Oscope Grant LP2018-5/2018.

Open Access This article is distributed under the terms of the Creative Commons Attribution 4.0 International License (http://creativecommons.org/licenses/by/4.0/), which permits unrestricted use, distribution, and reproduction in any medium, provided you give appropriate credit to the original author(s) and the source, provide a link to the Creative Commons license, and indicate if changes were made.

\section{References}

Ádám A, Wesztergom V (2001) An attempt to map the depth of the electrical asthenosphere by deep magnetotelluric measurements in the Pannonian Basin (Hungary). Acta Geol Hung 44(2-3):167-192

Ádám A, Szarka L, Novák A, Wesztergom V (2017) Key results on deep electrical conductivity anomalies in the Pannonian Basin (PB), and their geodynamic aspects. Acta Geod Geophys 52(2):205-228

Bada G, Horváth F, Dövéyi P, Szafián P, Windhoffer G, Cloetingh S (2007) Present-day stress field and tectonic inversion in the Pannonian basin. Glob Planet Change 58(1-4):165-180

Balázs A, Matenco L, Magyar I, Horváth F, Cloetingh SAPL (2016) The link between tectonics and sedimentation in back-arc basins: new genetic constraints from the analysis of the Pannonian Basin. Tectonics 35(6):1526-1559

Behm M, Brückl E, Mitterbauer U et al (2007) A new seismic model of the Eastern Alps and its relevance for geodesy and geodynamics. VGI Österr Z Vermess Geoinf 2:121-133

Bondár I, Myers SC, Engdahl ER, Bergman EA (2004) Epicentre accuracy based on seismic network criteria. Geophys J Int 156(3):483-496

Bondár I, Mónus P, Czanik C, Kiszely M, Gráczer Z, Wéber Z, AlpArrayWorking Group (2018) Relocation of seismicity in the Pannonian basin using a global 3D velocity model. Seismol Res Lett 89(6):2284-2293 
Bus Z (2001) Tomographic imaging of three-dimensional P-wave velocity structure beneath the Pannonian basin. Acta Geod Geophys Hung 36(2):189-205

Bus Z, Grenerczy G, Tóth L, Mónus P (2009) Active crustal deformation in two seismogenic zones of the Pannonian region-GPS versus seismological observations. Tectonophysics 474(1-2):343-352

Crotwell HP, Owens TJ, Ritsema J (1999) The TauP Toolkit: flexible seismic travel-time and ray-path utilities. Seismol Res Lett 70(2):154-160

Dando B, Stuart G, Houseman G, Hegedüs E, Brückl E, Radovanović S (2011) Teleseismic tomography of the mantle in the Carpathian-Pannonian region of central Europe. Geophys J Int 186(1):11-31

El-Sharkawy A, Meier TM, Lebedev S, Weidle C, Cristiano L (2017) Surface wave tomography across the Alpine-Mediterranean Mobile Belt. In: AGU fall meeting abstracts

Faccenna C, Becker TW, Auer L, Billi A, Boschi L, Brun JP, Capitanio FA, Funiciello F, Horváth F, Jolivet L et al (2014) Mantle dynamics in the Mediterranean. Rev Geophys 52(3):283-332

Gráczer Z, Wéber Z (2012) One-dimensional P-wave velocity model for the territory of Hungary from local earthquake data. Acta Geod Geophys Hung 47(3):344-357

Gráczer Z, Szanyi G, Bondár I, Czanik C, Czifra T, Győri E, Hetényi G, Kovács I, Molinari I, Süle B, Szűcs E, Wesztergom V, Wéber Z, AlpArray Working Group (2018) AlpArray in Hungary: temporary and permanent seismological networks in the transition zone between the Eastern Alps and the Pannonian basin. Acta Geodaetica et Geophysica 53(2):221-245

Grad M, Guterch A, Keller GR, Janik T, Hegedûs E, Vozár J, Ślaczka A, Tiira T, Yliniemi J (2006) Lithospheric structure beneath trans-Carpathian transect from Precambrian platform to Pannonian basin: CELEBRATION 2000 seismic profile CEL05. J Geophys Res: Solid Earth. https://doi. org/10.1029/2005JB003647

Grad M, Tiira T, Group EW (2009) The Moho depth map of the European Plate. Geophys J Int 176(1):279-292

Handy MR, Ustaszewski K, Kissling E (2015) Reconstructing the Alps-Carpathians-Dinarides as a key to understanding switches in subduction polarity, slab gaps and surface motion. Int J Earth Sci 104(1):1-26

Harangi S (2001) Neogene to Quaternary volcanism of the Carpathian-Pannonian Region-a review. Acta Geol Hung 44(2):223-258

Harangi S, Lenkey L (2007) Genesis of the Neogene to Quaternary volcanism in the Carpathian-Pannonian region: role of subduction, extension, and mantle plume. Spec Pap Geol Soc Am 418:67

Hetényi G, Ren Y, Dando B, Stuart GW, Hegedűs E, Kovács AC, Houseman GA (2015) Crustal structure of the Pannonian basin: the AlCaPa and Tisza terrains and the mid-Hungarian zone. Tectonophysics 646:106-116

Hetényi G, Molinari I, Clinton J, Bokelmann G, Bondár I, Crawford WC, Dessa JX, Doubre C, Friederich W, Fuchs F et al (2018) The AlpArray seismic network: a large-scale European experiment to image the Alpine Orogen. Surveys geophys 39(5):1009-1033

Horváth F (1993) Towards a mechanical model for the formation of the Pannonian basin. Tectonophysics 226(1-4):333-357

Horváth F, Bada G, Szafián P, Tari G, Ádám A, Cloetingh S (2006) Formation and deformation of the Pannonian basin: constraints from observational data. Geol Soc Lond Mem 32(1):191-206

Horváth F, Musitz B, Balázs A, Végh A, Uhrin A, Nádor A, Koroknai B, Pap N, Tóth T, Wórum G (2015) Evolution of the Pannonian basin and its geothermal resources. Geothermics 53:328-352

Houseman GA, Gemmer L (2007) Intra-orogenic extension driven by gravitational instability: Carpathian-Pannonian orogeny. Geology 35:1135-1138

International Seismological Centre (2013) On-line Bulletin. International Seismological Centre, Thatcham, United Kingdom. www.isc.ac.uk

Kalmár D, Süle B, Bondár I, Group AW et al (2018) Preliminary Moho depth determination from receiver function analysis using AlpArray stations in Hungary. Acta Geod Geophys 53(2):309-321

Kästle ED, El-Sharkawy A, Boschi L, Meier T, Rosenberg C, Bellahsen N, Cristiano L, Weidle C (2018) Surface wave tomography of the Alps using ambient-noise and earthquake phase velocity measurements. J Geophys Res Solid Earth 123(2):1770-1792

Kennett B, Engdahl E, Buland R (1995) Constraints on seismic velocities in the Earth from traveltimes. Geophys J Int 122(1):108-124

Király Á, Faccenna C, Funiciello F (2018) Subduction zones interaction around the Adria microplate and the origin of the Apenninic Arc. Tectonics 37(10):3941-3953

Kiss J (2009) A cel08 szelvény geofizikai vizsgálata—study of the geophysical data along the cel08 deep seismic litospheric profile. Magy Geofiz 50(2):59-74

Konečný V, Lexa J, Hojstričová V (1995) The Central Slovakia Neogene volcanic field: a review. Acta Vulcanol 7(2):63-78 
Kovacs I, Szabó C (2008) Middle Miocene volcanism in the vicinity of the Middle Hungarian zone: evidence for an inherited enriched mantle source. J Geodyn 45(1):1-17

Kovács I, Falus G, Stuart G, Hidas K, Szabó C, Flower MFJ, Hegedus E, Posgay K, Zilahi-Sebess L (2012) Seismic anisotropy and deformation patterns in upper mantle xenoliths from the central Carpathian-Pannonian region: Asthenospheric flow as a driving force for Cenozoic extension and extrusion? Tectonophysics 514:168-179

Lenkey L (1999) Geothermics of the Pannonian basin and its bearing on the tectonics of basin evolution. Ph.D. thesis, Vrije Universiteit, Amsterdam

Lenkey L, Dövényi P, Horváth F, Cloetingh S (2002) Geothermics of the Pannonian basin and its bearing on the neotectonics. EGU Stephan Mueller Spec Publ Ser 3:29-40

Posgay K, Bodoky T, Hegedüs E, Kovácsvölgyi S, Lenkey L, Szafián P, Takacs E, Timar ZA, Varga G (1995) Asthenospheric structure beneath a Neogene basin in southeast Hungary. Tectonophysics 252(1-4):467-484

Praus O, Pěčová J, Petr V, Babuška V, Plomerova J (1990) Magnetotelluric and seismological determination of the lithosphere-asthenosphere transition in central europe. Phys Earth Planet Inter 60(1-4):212-228

Rawlinson N, Sambridge M (2004) Multiple reflection and transmission phases in complex layered media using a multistage fast marching method. Geophysics 69(5):1338-1350

Rawlinson N, Reading AM, Kennett BL (2006) Lithospheric structure of Tasmania from a novel form of teleseismic tomography. J Geophys Res: Solid Earth. https://doi.org/10.1029/2005JB003803

Ren Y, Stuart G, Houseman G, Dando B, Ionescu C, Hegedüs E, Radovanović S, Shen Y, Group SCPW et al (2012) Upper mantle structures beneath the Carpathian-Pannonian region: implications for the geodynamics of continental collision. Earth Planet Sci Lett 349:139-152

Ren Y, Grecu B, Stuart G, Stuart G, Houseman G, Hegedü E, Group SCPW,.., (2013) Crustal structure of the Carpathian-Pannonian region from ambient noise tomography. Geophys J Int 195(2):1351-1369

Seghedi I, Downes H, Szakács A, Mason PR, Thirlwall MF, Roşu E, Pécskay Z, Márton E, Panaiotu C (2004) Neogene-Quaternary magmatism and geodynamics in the Carpathian-Pannonian region: a synthesis. Lithos 72(3):117-146

Song W, Yu Y, Shen C, Lu F, Kong F (2019) Asthenospheric flow beneath the Carpathian-Pannonian region: constraints from shear wave splitting analysis. Earth Planet Sci Lett 520:231-240

Szanyi G, Gráczer Z, Győri E (2013) Ambient seismic noise Rayleigh wave tomography for the Pannonian basin. Acta Geod Geophys 48(2):209-220

Tari G, Dövényi P, Dunkl I, Horváth F, Lenkey L, Stefanescu M, Szafián P, Tóth T (1999) Lithospheric structure of the Pannonian basin derived from seismic, gravity and geothermal data. Geol Soc Lond Spec Publ 156(1):215-250

Wéber Z (2002) Imaging Pn velocities beneath the Pannonian basin. Phys Earth Planet Inter 129(3-4):283-300 